\title{
CONFUSION DAN PEMBATALAN MEREK OLEH PENGADILAN
}

\section{Indirani Wauran* dan Titon Slamet Kurnia**}

Bagian Hukum Perdata dan Bagian Hukum Internasional,

Fakultas Hukum Universitas Kristen Satya Wacana, Salatiga

Jalan Diponegoro 52-60, Salatiga, Jawa Tengah 50711

\begin{abstract}
This article criticizes the judicial review practice over trademarks infringement in Indonesia. This article argues that to be fair the court should consider the confusion effect to determine whether there is a trademarks infringement case in accordance with Art. 16.1 of the TRIPs Agreement. This article concludes that Indonesia needs to improve its legislation to meet the requirement of the TRIPs Agreement and to improve the judges quality in applying the Trademarks Law properly by considering its purpose which grants the trademark owner a protection of the trademark's identity and a protection against confusion against unauthorized use by third parties.
\end{abstract}

Keyword: confusion, judicial review, trademark infringement.

\section{Intisari}

Artikel ini mengkritisi praktik yudisial atas kasus pelanggaran merek di Indonesia. Atas dasar itu artikel ini berargumen bahwa supaya adil maka pengadilan seyogianya mempertimbangkan efek kebingungan untuk menentukan apakah ada pelanggaran merek sesuai Art. 16.1 TRIPs Agreement. Artikel ini menyimpulkan bahwa Indonesia perlu memperbaiki legislasinya supaya sesuai tuntutan TRIPs Agreement dan meningkatkan kualitas hakimnya dalam menerapkan Hukum Merek secara memadai dengan mempertimbangkan aspek purposivenya untuk memberikan kepada pemilik merek perlindungan atas identitas mereknya itu sendiri dan perlindungan atas kebingungan yang ditimbulkan oleh penggunaan merek tanpa hak oleh pihak ketiga. Kata Kunci: kebingungan, pengujian yudisial, pelanggaran merek.

\section{Pokok Muatan}

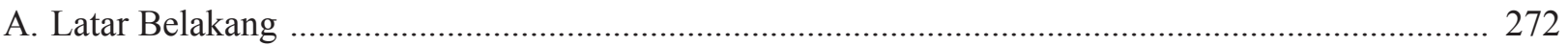

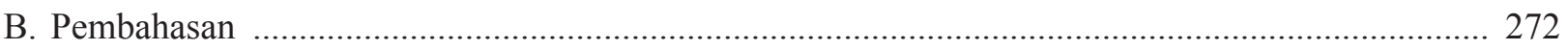

1. Confusion sebagai Dasar Pengujian Pelanggaran Merek ....................................................... 272

2. Kelemahan Legislasi dan Ajudikasi dalam Perlindungan Merek di Indonesia .......................... 277

3. Amandemen Undang-Undang Merek dan Ajudikasi yang Lebih Konstruktif dengan Hakikat

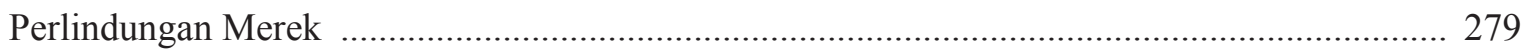

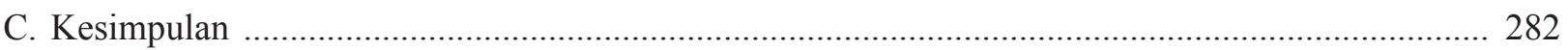

\footnotetext{
Alamat korespondensi: indirani.wauran@staff.uksw.edu

** Alamat korespondensi: titonslamet@gmail.com
} 


\section{A. Pendahuluan}

Tulisan ini akan membahas secara khusus tentang pembatalan merek oleh pengadilan (judicial review of trademarks infringement) di Indonesia. Adapun isu hukum terkait praktik tersebut adalah pendekatan dalam pengujian oleh pengadilan atas kasus pelanggaran merek yang cenderung dilakukan secara sumir dengan mengikuti ketentuan UndangUndang Nomor 15 Tahun 2001 tentang Merek (UU Merek) sebagai syarat pembatalannya, yaitu terpenuhinya unsur "persamaan pada pokoknya" suatu merek terdaftar dengan merek terdaftar milik pihak lain yang ada lebih dahulu. ${ }^{1}$ Pendekatan demikian sejatinya kurang mempertimbangkan aspek fairness dalam pemilikan merek yang sah.

Terkait dengan isu tersebut artikel ini berargumen bahwa praktik yudisial dalam pembatalan merek di Indonesia cenderung tidak fair karena mengabaikan elemen substantif bahwa bukan hanya "persamaan pada pokoknya" yang menjadi isu, tetapi juga "adanya kebingungan" (likelihood of confusion), sebagai akibat, yang ditimbulkan oleh adanya persamaan atau kemiripan tersebut juga hendaknya dipertimbangkan oleh pengadilan. Argumen ini secara spesifik mengacu pada Art. 16.1 Trade Related Aspects of the Intellectual Property Rights (selanjutnya disebut TRIPs Agreement) ${ }^{2}$ yang merumuskan ketentuan terkait dengan standar perlindungan merek secara internasional sebagai berikut:

The owner of a registered trademark shall have the exclusive right to prevent all third parties not having the owner's consent from using in the course of trade identical or similar signs for goods or services which are identical or similar to those in respect of which the trademark is registered where such use would result in a likelihood of confusion. In case of the use of an identical sign for identical goods or services, a likelihood of confusion shall be presumed. ${ }^{3}$

Dalam pembahasan ini penulis cenderung berpendirian supaya standar yang telah diletakkan di dalam TRIPs tersebut untuk diikuti secara konsisten oleh Indonesia baik pada tataran legislasi maupun, secara lebih spesifik lagi, dalam tataran ajudikasi. Terkait dengan itu, sistematika pembahasan artikel ini, dalam rangka mempertahankan argumen di atas, dapat dijabarkan sebagai berikut. Pertama, penulis akan berargumen tentang perlunya syarat confusion sebagai dasar pengujian dalam pembatalan merek secara yudisial. Kedua, penulis akan menggambarkan kelemahan yang ada dalam legislasi serta penerapannya dalam ajudikasi di Indonesia. Ketiga, penulis akan menjelaskan implikasi dari argumen tersebut berupa perlunya amandemen atau perubahan terhadap UU Merek serta bagaimana hakim seyogianya memutus kasus pelanggaran merek.

\section{B. Pembahasan \\ 1. Confusion sebagai Dasar Pengujian Pe- langgaran Merek}

Seperti telah penulis nyatakan di atas, artikel ini secara spesifik menganut pendirian bahwa syarat terjadinya confusion (kebingungan) seyogyanya menjadi pertimbangan dalam pengujian pelanggaran merek secara yudisial; bukan hanya syarat persamaan atau kemiripannya kemiripannya semata. Syarat demikian dikonsepsikan likelihood of confusion sebagai akibat yang timbul (would result in a likelihood of confusion $).{ }^{4}$ Pendirian ini

Kaidah demikian dapat disimpulkan dengan mengacu pada Pasal 6 UU Merek yang menentukan bahwa suatu pendafataran merek harus ditolak jika merek yang hendak didaftarkan memiliki persamaan pada pokoknya dengan merek terdaftar milik pihak lain. Lihat Pasal 6 Undang-Undang Nomor 15 Tahun 2001 tentang Merek (Lembaran Negara Republik Indonesia Tahun 2001 Nomor 110, Tambahan Lembaran Negara Republik Indonesia Nomor 4131).

Marrakesh Agreement Establishing the World Trade Organization, opened for signature 15 April 1994, 1867 UNTS 3 (entered into force 1 January 1995), annex 1C (Agreement on Trade-Related Aspects of Intellectual Property Rights) 1867 UNTS 299, incorporating by reference the Paris Convention for the Protection of Industrial Property, opened for signature 14 July 1967, 828 UNTS 306 (entered into force 26 April 1970) ('Paris Convention') and the Berne Convention for the Protection of Literary and Artistic Works, opened for signature 14 July 1967, 828 UNTS 222 (entered into force 29 January 1970) ('Berne Convention').

TRIPs Agreement adalah bagian dari Agreement Establishing the World Trade Organization (WTO Agreement) yang telah diratifikasi Indonesia dengan Undang-Undang Nomor 7 Tahun 1994 tentang Pengesahan Agreement Establishing The World Trade Organization (Persetujuan Pembentukan Oorganisasi Perdagangan Dunia) (Lembaran Negara Republik Indonesia Tahun 1994 Nomor 57).

Article 16.1 TRIPs Agreement. 
berusaha untuk secara taat asas mengikuti ketentuan Art. 16.1 TRIPs Agreement serta ditunjang oleh rationale bahwa hal ini akan mampu menghasilkan praktik ajudikasi yang lebih fair.

Pendirian demikian sejatinya paralel dengan pendapat Jan Hendrik Schmidt-Pfitzner yang memberikan anotasi atas makna ketentuan Art. 16.1 TRIPs Agreement. Secara teleologis atau purposive Schmidt-Pfitzner menangkap hakikat perlindungan merek dari ketentuan tersebut adalah "grants the trademark owner both a protection of the trademark's identity and a protection against confusion - exclusively, however, against unauthorized use by third parties". ${ }^{5}$ Artinya, mengacu pada pernyataan di atas, tetapi hal ini terlampau sering diabaikan di Indonesia, $a$ protection against confusion merupakan salah satu semangat dalam perlindungan merek sebagaimana dikehendaki oleh Art. 16.1 TRIPs Agreement. Dengan demikian, a fortiori, syarat confusion sangat kontekstual maknanya sebagai dasar pengujian pelanggaran merek karena paralel dengan aspek teleologis atau purposive dari perlindungan hukum terhadap merek itu sendiri sehingga menjadikan hasil dari ajudikasi tersebut lebih fair.

Selain konsep likelihood of confusion, sebenarnya dikenal pula konsep confusingly similar. ${ }^{6}$ Kedua konsep secara harafiah cenderung mirip namun maknanya sedikit berbeda. Confusingly similar dapat diartikan kemiripan yang membingungkan, sedangkan likelihood of confusion mengandung makna adanya kemungkinan akan terjadi kebingungan. Dengan demikian diperoleh pengertian bahwa kebingungan dapat diartikan sebagai keadaan bingung yang sudah terjadi dan juga keadaan bingung yang mungkin akan terjadi.
Kemungkinan terjadi kebingungan (likelihood of confusion) sering terkait dengan kemungkinan terjadinya asosiasi (likelihood of association) antara satu merek dengan merek lain. ${ }^{7}$ Sebagai contoh kasus Wagamama Ltd v. City Centre Restaurant plc. ${ }^{8}$ Penggugat memiliki restoran masakan Jepang yang sukses di London dengan nama WAGAMAMA, kemudian pada April 1995 penggugat membuka restoran yang menjual masakan India dengan nama Rajamama. Dalam kasus ini Justice Laddie berpendapat pada frase yang menjadi pokok gugatan menyatakan likelihood of confusion termasuk likelihood of association karena frase yang kemudian (mama) dianggap lebih luas daripada frase yang terdahulu. Dengan kata lain, asosiasi (likelihood of association) akan dianggap melanggar merek hanya jika ada kemungkinan terjadi kebingungan (likelihood of confusion) di masyarakat. Dengan demikian kaidah hukum putusan ini ialah likelihood of association hanya satu contoh bentuk kebingungan.

Pada awal abad ke-20, likelihood of association dibatasi pada barang atau jasa sejenis. Hal itu bertujuan untuk melindungi konsumen dari kesalahan dalam membeli produk karena konsumen salah dalam mengidentifikasi merek tertentu. Dengan kata lain, konsumen hanya akan pergi ke produk yang ditawarkan oleh pelaku usaha yang melanggar merek jika pelaku usaha tersebut menjual barang atau jasa yang sejenis dengan merek yang dilanggar. ${ }^{9}$ Hal ini nampak dalam kasus klasik Borden Ice Cream Co v. Borden's Condensed Milk $\mathrm{Co}^{10}$ di mana pengadilan menolak klaim yang diajukan penggugat bahwa telah terjadi pelanggaran hak merek BORDEN untuk es krim karena penggugat menggunakan merek

\footnotetext{
Anotasi tersebut dimuat dalam Jan Hendrik Schmidt-Pfitzner, Article I6: "Rights Conferred", dalam Peter-Tobias Stoll, Jan Busche dan Katrin Arend, 2009, WTO: Trade Related Aspects of Intellectual Property Rights, Martinus Nijhoff Publishers, Leiden-Boston, hlm. 318.

Konsep confusingly similar digunakan di dalam the Restatement (First) of Torts $\S 729$ (1938) Sec. 729 yang disusun oleh the American Law Institute.

David I. Bainbridge, 1999, Intellectual Property, Pitman Publishing, London, hlm. 572.

Wagama Ltd v. City Centre Restaurant plc [1995] Federal Sentecing Reporter (FSR) 713. sebagaimana dikutip dalam David I. Bainbridge, Ibid.

Mark A. Lemley dan Mark McKenna, "Irrelevant Confusion”, Stanford Law Review, Vol. 62, 2009, hlm. 422.

10 Borden Ice Cream Co v. Borden's Condensed Milk Co. 201 F. 510 ( $7^{\text {th }}$ Circuits. 1912), sebagaimana dikutip dalam Mark A. Lemley dan Mark McKenna, Ibid.
} 
BORDEN untuk susu dan produk terkait. ${ }^{11}$ Meski pengadilan mengakui bahwa penggunaan secara terus menerus atas merek BORDEN untuk es krim dan susu mungkin akan membingungkan konsumen (mengenai asal-usul barang). Namun hal ini tidak mengubah fakta bahwa orang yang menginginkan susu tidak akan membeli es krim karena kesalahan.

Dalam perkembangannya, perlindungan merek diberikan untuk barang tidak sejenis. Dalam kasus Aunt Jemima Molls Co. v. Rigney \& Co., ${ }^{12}$ Aunt Jemima - merek untuk sirup - menuduh Rigney telah melanggar mereknya dengan menggunakan merek AUNT JEMIMA untuk tepung. Jika menganut prinsip yang sama seperti kasus Borden Ice Cream Co v. Borden's Condensed Milk Co. maka pengadilan akan memutuskan tidak ada pelanggaran merek karena "orang yang akan membeli sirup tidak akan membeli tepung". Namun dalam kasus ini pengadilan memutuskan ada pelanggaran merek atas dasar produk (yang dijual) sangat terkait satu sama lain. Dengan demikian likelihood of confusion ditentukan pula oleh produk di mana merek dilekatkan, apakah produk tersebut saling terkait atau tidak. Apabila produk merupakan produk yang saling terkait (closely related goods), maka likelihood of confusion - dalam hal ini kebingungan mengenai asal produk (source of origin) - dapat terjadi.

Sampai pada titik ini diketahui bahwa pengadilan mengartikan kebingungan terjadi apabila persamaan atau kemiripan tersebut menyebabkan konsumen berpikir bahwa produk berasal dari produsen yang sama atau pemilik merek tertentu terafiliasi dengan merek pada produk lainnya. ${ }^{13}$ Oleh karena itu, perlindungan merek harus dapat diperluas sehingga mencakup perlindungan atas penggunaan yang menyebabkan kebingungan di kalangan konsumen mengenai siapakah pihak yang bertanggung jawab atas kualitas suatu barang atau jasa. ${ }^{14}$ Penggunaan merek yang mengakibatkan kebingungan seperti itu harus dikategorikan sebagai pelanggaran merek karena pada hakikatnya hukum merek harus mencegah para pihak membuat kesan yang keliru (misimpression). Dengan kalimat berbeda dapat dikatakan bahwa kasus confusion melibatkan produk yang tidak saling bersaing dan berfokus pada dampak yang dialami oleh pihak ketiga (konsumen) terkait dengan pesan yang diterima melalui merek akan kualitas barang tertentu. ${ }^{15}$ Namun, penelitian mengenai perluasan merek ternyata menunjukkan bahwa produsen seringkali tidak dirugikan ketika konsumen keliru mengasosiasikan suatu produk yang sebenarnya tidak berhubungan dengan produsen tersebut. ${ }^{16}$

Adapun isu substansial yang belum terjawab di sini adalah pengertian mengenai apa yang harus dibingungkan. Konsep kebingungan dalam pengertian klasik adalah situasi di mana konsumen meyakini bahwa suatu produk berasal dari satu organisasi padahal pada kenyataannya tidak. ${ }^{17}$ Pengertian ini kemudian berkembang dengan memasukkan kebingungan mengenai adanya economic connection. ${ }^{18}$ Kasus yang relevan di sini adalah kasus landmark Canon Kabushiki Kaisha v. Metro-Goldwyn-Mayer Inc., yang diputuskan oleh the European Court of Justice: "the risk that the public might believe that the goods or services in question come from the same undertaking or, as the case may be, from economically-linked undertakings, constitutes a likelihood of con-

\footnotetext{
Borden Ice Cream Co v. Borden's Condensed Milk Co. lebih lanjut lihat Mark A. Lemley dan Mark McKenna, Ibid., hlm. 515.

Aunt Jemima Molls Co. v. Rigney \& Co.247 F. 407, 408 (2 ${ }^{\text {nd }}$ Circuit 1917). Penerapan prinsip yang sama juga terjadi dalam putusan Vogue Co. v. Thompson-Hudson Co. 300 F. $5096^{\text {th }}$ Circuits. 1924) sebagaimana dikutip dalam Mark A. Lemley dan Mark McKenna, Ibid.

Ibid., hlm. 426.

Ibid., hlm. 427.

Bandingkan dengan Mark McKenna, “Testing Modern Trademark Law's Theory of Harm”, Iowa Law Review, Vol. 95, 2009, hlm. 84.

Ibid., hlm. 115.

Lionel Bently dan Brad Sherman, 2001, Intellectual Property Law, Oxford University Press, Oxford, hlm. 822-823. Tentang praktik yang biasa digunakan pengadilan Amerika Serikat dalam menentukan ada/tidaknya confusion dengan menggunakan pendekatan multi-factor test. Lihat Barton Beebe, “An Empirical Study of the Multifactor Test for Trademark Infringement”, California Law Review, Vol. 94, 2006, hlm. 1591.
}

18 Ibid. 
fusion". ${ }^{19}$ Namun perlu diingat bahwa dalam mempertimbangkan adanya likelihood of confusion, pengadilan harus melihat apakah benar-benar terjadi kebingungan dan bukan hanya hipotetis. ${ }^{20}$ Dengan demikian kata likelihood harus diartikan probability daripada possibility; ${ }^{21}$ artinya, kebingungan tersebut harus benar-benar akan terjadi dan bukan sekedar dapat terjadi.

Hakim memiliki tanggung jawab sangat strategis dalam menyatakan bahwa konsumen akan mengalami kebingungan dari keberadaan dua merek. ${ }^{22}$ Untuk membantu hakim dalam memutuskan, hakim dapat mempertimbangkan bukti-bukti yang diajukan oleh para pihak. Adapun bukti yang dimaksud antara lain berupa kesaksian konsumen yang independen dan dapat dipercaya, kesaksian ahli mengenai struktur pasar, dan juga survei apakah antara dua merek memiliki persamaan yang membingungkan. ${ }^{23}$

Sulitnya menentukan apakah keberadaan dua merek atau lebih akan menimbulkan kebingungan di kalangan konsumen tercermin dari adanya berbagai kriteria atau batu uji. Beebe dalam penelitiannya menemukan bahwa tiga belas United States Circuit Court $^{24}$ memiliki multifactor test yang berbedabeda untuk menentukan kemungkinan akan ada kebingungan di kalangan konsumen. ${ }^{25}$ Selanjutnya, dalam penelitiannya, Beebe juga menemukan bahwa pada akhirnya hakim menerapkan prinsip fast and frugal atau cepat dan cermat untuk memperpendek daftar faktor yang panjang. ${ }^{26}$ Hal ini disebabkan karena beberapa faktor terbukti menentukan; selebihnya jika bukan merupakan pengulangan justru tidak relevan. ${ }^{27}$
Adapun gabungan seluruh faktor yang digunakan menjadi batu uji dari ketiga belas United States Circuit Court dalam menentukan adanya likelihood of confusion yaitu: ${ }^{28}$ (a) similarity of the marks; (b) proximity of the Goods; (c) evidence of actual confusion; (d) strength of plaintiff's mark; (e) defendant's intent; (f) sophistication of the consumers; (g) similarity of advertising methods, marketing methods; (h) similarity of sales facilities; (i) likelihood of bridging the gap; (j) comparative quality of the goods; (k) length of time concurrent use without evidence of actual confusion; (1) extent to which targets of parties sales efforts are the same; (m) third-party uses of plaintiff's mark; (n) variety of goods on which mark is used; (o) market interface between applicant and owner of prior mark; (p) extent of applicant's right to exclude; (q) extent of potential confusion, i.e. whether di minimis or substantial; (r) any other established fact probative of effect of use; (s) strength of plaintiff's mark in defendant's geographically-district market.

Sebagai informasi, faktor pertama sampai dengan keempat ditemukan dalam semua United States Circuit Court, sementara faktor yang kelima ditemukan dalam semua United States Circuit Court kecuali Federal Circuit. ${ }^{29}$ Dalam menerapkan multifactor test tersebut, ada beberapa prinsip yang harus diingat yaitu: multifactor test tersebut haruslah tidak diterapkan secara mekanis; ${ }^{30}$ selanjutnya, daftar faktor tersebut bukan merupakan daftar yang tertutup, ${ }^{31}$ beberapa faktor bisa jadi lebih penting dari faktor yang lain sementara ada beberapa yang mungkin tidak relevan, ${ }^{32}$ dan prinsip yang terakhir kesimpulan dari penerapan multifactor test tersebut

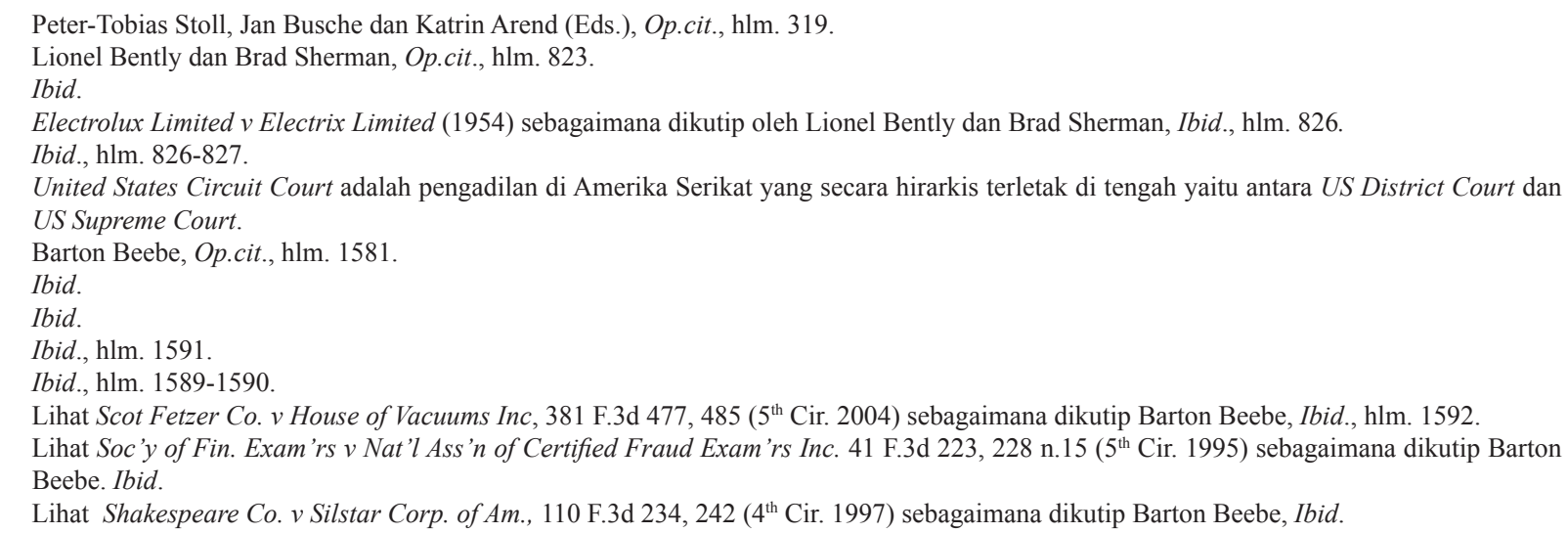


tidak dapat dengan semata-mata menentukan pihak yang memenangkan faktor lebih banyak. ${ }^{33}$

Dari sembilan belas faktor tersebut, terbukti hanya terdapat lima faktor inti yang berperan sebagai batu uji dalam menentukan ada atau tidaknya likelihood of confusion dan lebih berpengaruh terhadap faktor-faktor yang lain. ${ }^{34}$ Adapun faktor inti tersebut dalam urutan yang mempertimbangkan tingkat pentingnya faktor tersebut adalah: (a) the similarity of the marks; (b) defendant's intent; (c) proximity of the goods; (d) the strength of plaintiff's mark; and (e) evidence of actual confusion. Masingmasing faktor inti akan dijelaskan dalam paragraf berikut ini.

Pertama, the similarity of the marks atau kemiripan di antara dua merek. Faktor ini merupakan faktor yang utama dibandingkan keseluruhan faktor yang lain. Hal ini dapat dimengerti karena apabila di antara kedua merek tidak ada kesamaan, sulit dibayangkan konsumen akan mengalami kebingungan mengenai kedua merek tersebut. ${ }^{35}$ Menentukan kemiripan antar dua merek juga bukan merupakan hal yang mudah. Doktrin mendorong hakim untuk mempertimbangkan kesamaan bunyi suara, penampakan merek, dan makna merek; melihat merek sebagai satu kesatuan, dan menekankan pada persamaan daripada perbedaan di antara kedua merek.

Kedua, defendant intent atau niat tergugat. Faktor ini memiliki peran yang signifikan dalam menentukan apakah ada likelihood of confusion. Apabila dalam persidangan terbukti bahwa ada niat dari tergugat untuk meniru merek lain, maka hakim memutuskan bahwa ada likelihood of confusion terlepas dari fakta apakah konsumen benar-benar mengalami 'kebingungan' atau tidak. ${ }^{36}$ Dalam hal ini berlaku prinsip siapa yang tidak menabur tidak boleh menuai. Berlaku pula prinsip bahwa pohon yang baik akan menghasilkan buah yang baik, demikian pula sebaliknya. Dengan demikian, doktrin ini dimaksudkan untuk mendorong moralitas dalam kegiatan perdagangan.

Ketiga, proximity of the goods atau kedekatan di antara barang di mana merek dilekatkan. Kedekatan yang dipertimbangkan di sini bukan merek itu sendiri namun barang di mana merek dilekatkan. Ini dimaksudkan untuk mempertimbangkan apakah barang yang ditawarkan cukup memiliki kesamaan sehingga konsumen dapat mengasumsikan bahwa kedua merek yang disengketakan berasal dari sumber yang sama. ${ }^{37}$

Keempat, the strength of plaintiff's mark atau kekuatan merek penggugat. Kekuatan merek penggugat berbanding lurus dengan perlindungan yang diberikan. Artinya, semakin kuat merek milik penggugat maka perlindungan yang diberikan juga semakin kuat. Dalam konteks multifactor test untuk menilai adanya likelihood of confusion, hakim cenderung menyatakan bahwa ada likelihood of confusion jika merek dikategorikan sebagai merek yang kuat (memiliki inherent strength). Tentu saja hal ini dapat tidak sesuai dengan fakta yang sesungguhnya terjadi mengenai apakah ada 'kebingungan' yang nyata-nyata dialami oleh konsumen. Oleh karenanya dapat dikatakan bahwa faktor ini mendorong penggunaan merek yang memiliki daya pembeda yang kuat (inherently distinctive) daripada merekyang 'hanya' deskriptif. ${ }^{38}$

Kelima, evidence of actual confusion atau bukti bahwa benar-benar terjadi kebingungan di kalangan konsumen. Dalam kasus ini demikian pengadilan mempertimbangkan dua bentuk bukti yaitu: (1) survei (survey evidence) dan (2) bukti langsung (direct evidence) seperti kesaksian konsumen yang mengalami kebingungan dari penggunaan merek oleh tergugat. ${ }^{39}$ Secara umum

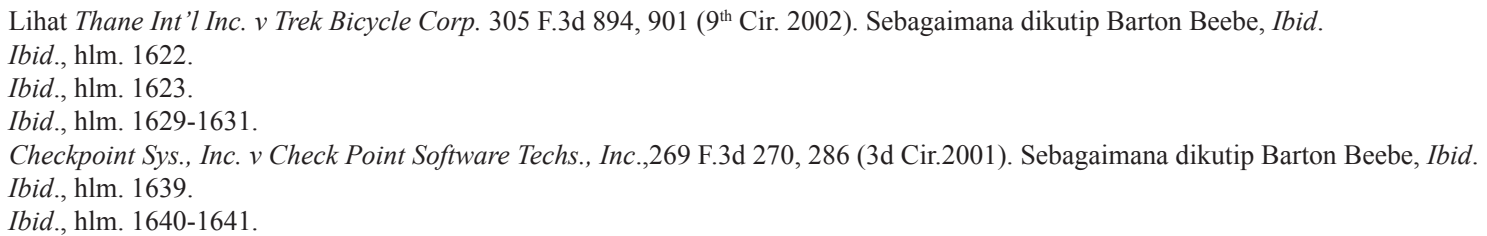


dapat disimpulkan bahwa survei kepada konsumen merupakan bukti paling baik untuk mencari apakah benar terjadi kebingungan di kalangan konsumen. Hasil survei yang dilakukan dengan baik berpotensi dapat mengalahkan pertimbangan dari seluruh faktor yang lain. Namun demikian penelitian Beebe yang melibatkan 331 putusan menunjukkan bahwa hanya 24 putusan hakim (setara dengan 7\%) yang amar putusannya memihak pada hasil survei tersebut. $^{40}$

Isu terakhir ialah justifikasi untuk argumen hasil yang lebih fair dengan dipertimbangkannya syarat confusion. Penulis berpendapat bahwa ketika konsumen tidak mengalami kebingungan mengenai dua merek yang memiliki persamaan atau kemiripan maka hal itu menunjukkan bahwa fungsi merek sebagai daya pembeda telah terpenuhi. Atas dasar itu maka melindungi kedua merek tersebut bersama-sama, dalam kerangka hukum merek sendiri, merupakan kondisi yang lebih fair ketimbang membatalkan salah satunya.

Memberikan keleluasaan bagi seseorang untuk menikmati hak merek yang dimilikinya merupakan wujud dari keadilan. Demikian pula mencegah pihak lain menggunakan merek terdaftar secara tanpa izin merupakan manifestasi keadilan. Tujuan awal pemberian hak merek pada hakikatnya adalah untuk memperlancar dunia perdagangan, oleh karenanya jika tujuan ini tetap terpenuhi - dalam arti konsumen tidak mengalami kebingungan dengan adanya dua merek yang sama atau mirip - maka seharusnya kedua merek tersebut layak digunakan sebagai merek karena masing-masing memiliki daya pembeda. Oleh karena itu, melindungi kedua merek tersebut merupakan bentuk perlindungan hak milik yang adalah manifestasi keadilan.

Daya pembeda sebagai fungsi inheren merek yang berhubungan dengan barang atau jasa dalam lalu lintas perdagangan sangat fundamental maknanya. ${ }^{41}$ Hal ini bertujuan untuk membantu memandu atau mengarahkan konsumen dalam memilih atau mengidentifikasi produk barang atau jasa sesuai dengan yang dikehendakinya. Dikaitkan dengan pendapat Bainbridge yang penulis setujui, merek secara fungsional menjelaskan mengenai asal-usul suatu barang yang mencerminkan kualitas barang tertentu. ${ }^{42}$ Oleh karena itu, dalam kasus ini, konsep daya pembeda sangat vital fungsinya, sehingga syarat confusion tersebut menjadi sangat relevan konteksnya dalam kaitan dengan konsep daya pembeda sebagai fungsi pada merek. Hal ini juga didukung oleh kemungkinan sebab terjadinya kemiripan antar merek yang sangat beragam bermacam-macam. Faktor ketidaksengajaan atau kebetulan sangat besar kemungkinannya untuk terjadi selain faktor kesengajaan untuk mendompleng merek milik pihak lain. Oleh karena itu pengujian yudisial atas kasus-kasus pelanggaran merek perlu lebih substansial, tidak hanya fokus pada unsur persamaan atau kemiripan belaka dari merek, tetapi juga akibat dari persamaan atau kemiripan itu yang menimbulkan kebingungan pada konsumen (likelihood of confusion) dan karena kebingungan itu maka pemilik merek menjadi dirugikan.

\section{Kelemahan Legislasi dan Ajudikasi dalam Perlindungan Merek di Indonesia}

Sub-judul ini akan menjelaskan kelemahan UU Merek dan implikasinya pada praktik ajudikasi kasus-kasus pelanggaran merek. Argumen penulis di sini adalah sumirnya pertimbangan hakim dalam ajudikasi kasus-kasus pelanggaran merek yang hanya menekankan pada aspek persamaan pada pokoknya merupakan implikasi dari tidak memadainya preskripsi UU Merek dalam menentukan kriteria pelanggaran merek karena hanya bertumpu pada syarat persamaan pada pokoknya sebagai dasar pengujian.

UU Merek tidak mengatur secara spesifik kriteria pelanggaran merek. Namun dengan interpretasi sistematis dapat disimpulkan bahwa

\footnotetext{
$40 \quad$ Ibid., hlm. 1641.

41 Hal itu menjelaskan mengapa konsep daya pembeda menjadi unsur dalam definisi yuridis merek sesuai Pasal 1 angka 1 Undang-Undang Nomor 15 Tahun 2001 tentang Merek (Lembaran Negara Republik Indonesia Tahun 2001 Nomor 110, Tambahan Lembaran Negara Republik Indonesia Nomor 4131).

42 David I. Bainbridge, Op.cit., hlm. 524.
} 
pelanggaran merek pada hakikatnya adalah menggunakan merek yang sama pada keseluruhannya atau sama pada pokoknya dengan merek terdaftar milik pihak lain untuk barang dan atau jasa sejenis yang diproduksi atau diperdagangkan secara sengaja dan tanpa hak. ${ }^{43}$ Persamaan pada pokoknya disebut secara khusus dalam Pasal 6 UU Merek dan Penjelasannya di mana ketentuan ini pada hakikatnya tentang alasan penolakan dalam pendaftaran merek karena memiliki persamaan pada pokoknya dengan merek terdaftar milik pihak lain. Penjelasan Pasal 6 menyatakan bahwa persamaan pada pokoknya menitikberatkan pada adanya kemiripan. ${ }^{44}$ Pengaturan demikian jelas jauh dari memadai jika dibandingkan dengan Art. 16.1 TRIPs Agreement.

Mengingat UU Merek tidak mensyaratkan likelihood of confusion maka wajar adanya jika dalam ajudikasi kasus-kasus pelanggaran merek syarat tersebut tidak dipertimbangkan hakim. Kalaupun hakim menyatakan bahwa penggunaan merek yang memiliki persamaan pada pokoknya tersebut dapat menimbulkan kebingungan, namun hal itu tanpa didukung dengan ratio decidendi atau legal reasoning memadai. Berikut adalah beberapa contoh putusan Mahkamah Agung Republik Indonesia (MA) yang menjustifikasi kebenaran klaim tersebut: putusan perkara merek AKIRA, ${ }^{45}$ perkara merek $A Q U A$ v. $A Q U A C U I,{ }^{46}$ perkara merek GAP v. GAPPA, ${ }^{47}$ dan perkara merek KS. ${ }^{48}$

Dalam kebanyakan kasus, MA yang memutus perkara pelanggaran merek pada tingkat kasasi maupun peninjauan kembali merasa telah cukup puas dengan hanya menyatakan bahwa kedua merek memiliki unsur yang dominan dan menonjol untuk menentukan adanya persamaan pada pokoknya. ${ }^{49}$ Dalam hal ini, pertimbangan hukum tanpa ratio decidendi digunakan sebagai dasar amar putusan yang menyatakan bahwa salah satu merek tidak layak beredar dalam kegiatan perdagangan. Sebagai contoh, dalam perkara merek AQUA v AQUALIVA, Hakim MA mempertimbangkan bahwa antara kata aqua dan aqualiva memiliki persamaan pada pokoknya karena unsur yang dominan yaitu kata aqua. ${ }^{50}$ Pertimbangan ini berbeda dengan pertimbangan hakim Pengadilan Niaga yang mempertimbangkan bahwa adanya kemiripan saja tidak cukup untuk menentukan adanya persamaan pada pokoknya namun harus pula mempertimbangkan bahwa

43 Lihat Pasal 3, 4, 76, 90, dan 91 Undang-Undang Nomor 15 Tahun 2001 tentang Merek (Lembaran Negara Republik Indonesia Tahun 2001 Nomor 110, Tambahan Lembaran Negara Republik Indonesia Nomor 4131).

44 Kemiripan yang disebabkan oleh adanya unsur-unsur yang menonjol antara merek yang satu dengan merek yang lain yang dapat menimbulkan kesan adanya persamaan baik mengenai bentuk, cara penempatan, cara penulisan atau kombinasi antara unsur-unsur ataupun persamaan bunyi ucapan yang terdapat dalam merek-merek tersebut.

Putusan Mahkamah Agung Nomor $08 \mathrm{~K} / \mathrm{N} / \mathrm{HaKI} / 2003$ perihal Perkara Merek AKIRA.

6 Putusan Mahkamah Agung Nomor $011 \mathrm{~K} / \mathrm{N} / \mathrm{HaKI} / 2003$ perihal Perkara Merek AQUA-AQUACUI.

Putusan Mahkamah Agung Nomor $025 \mathrm{~K} / \mathrm{N} / \mathrm{HaKI} / 2006$ perihal Perkara Merek GAP - GAPPA.

4 Putusan Mahkamah Agung Nomor 358 K/Pdt.Sus-HaKI/20103 perihal Perkara Merek KRAKATAU STEEL.

49 Lihat Putusan Mahkamah Agung Nomor 01/PK/N/HaKI 2003 perihal Perkara Merek 100 dan Lukisan; Putusan Mahkamah Agung Nomor 06 PK/N/HaKI/2004 perihal Perkara Merek Extra Joss vs Enerjoss; Putusan Mahkamah Agung Nomor 014 K/N/HaKI/2003 perihal Perkara Merek AQUA - AQUALIVA; Putusan Mahkamah Agung Nomor 017 K/N/HaKI/2003 perihal Perkara Merek AQUA - INDOQUALITY; Putusan Mahkamah Agung Nomor 019 K/N/HaKI/2005 perihal Perkara Merek NEW FUJITA - FUJITA; Putusan Mahkamah Agung Nomor 020 K/N/HaKI/2007 perihal Perkara Merek GS YUASA - GS GOLDSTAR; Putusan Mahkamah Agung Nomor 027 K/N/HaKI/2003 perihal Perkara Merek SUNSWET \& DEVICE - SUNDAY \& DEVICE; Putusan Mahkamah Agung Nomor 027 K/N/HaKI/2006 perihal Perkara Merek VIM KHO - VIN KHO; Putusan Mahkamah Agung Nomor 032 K/N/HaKI/2003 perihal Perkara Merek PIONEER; Putusan Mahkamah Agung Nomor 033 K/N/HaKI/2003 perihal Perkara Merek AQUA - AQUA Tiruan; Putusan Mahkamah Agung Nomor 035 K/N/HaKI/2003 perihal Perkara Merek AQUA - AQUA Tiruan; Putusan Mahkamah Agung Nomor 038K/N/HaKI/2003 perihal Perkara Merek BONCAFE dan Logo; Putusan Mahkamah Agung Nomor 138 PK/Pdt.Sus/2011 perihal Perkara Merek MALING; Putusan Mahkamah Agung Nomor 165 PK/Pdt.Sus/2012 perihal Perkara Merek IKEA; Putusan Mahkamah Agung Nomor 177 K/Pdt.Sus/2012 perihal Perkara Merek MAXIMA - MAXISTYLE; Putusan Mahkamah Agung Nomor 202 K/Pdt.Sus/2010 perihal Perkara Merek IPSTAR BRADBAND SATELLITE KIPSTAR; Putusan Mahkamah Agung Nomor 292 K/Pdt.Sus/2009 perihal Perkara Merek POLO; Putusan Mahkamah Agung Nomor370 K/Pdt.Sus/2008 perihal Perkara Merek SOPHOMORE INTERNATIONAL; Putusan Mahkamah Agung Nomor 384 K/Pdt.Sus/2012 perihal Perkara Merek CHRISTIAN DIOR - CHARLES DIOR's; Putusan Mahkamah Agung Nomor 400 K/Pdt.Sus/2011 perihal Perkara Merek INTER-CONTINENTAL - INTERCONTINENTAL; Putusan Mahkamah Agung Nomor 415K/Pdt.Sus/2008 perihal Perkara Merek KNO3 (KENOTELU) - MEROKEKALINITRA dan KALINITRA; Putusan Mahkamah Agung Nomor 445 K/Pdt.Sus/2012 perihal Perkara Merek TEFLON; Putusan Mahkamah Agung Nomor 477 K/Pdt.Sus/2012 perihal Perkara Merek EVERLAST - EVER-LAST; Putusan Mahkamah Agung Nomor $501 \mathrm{~K} /$ Pdt.Sus-HKI/2013 perihal Perkara Merek ALLADIN - ALADIN; Putusan Mahkamah Agung Nomor 819 K/Pdt. Sus/2008 perihal Perkara Merek AMCO; Putusan Mahkamah Agung Nomor 975 K/Pdt.Sus/2005 perihal Perkara Merek GIORGIO.

50 Putusan Mahkamah Agung Nomor 014 K/N/HaKI/2003 perihal Perkara Merek AQUA - AQUALIVA, hlm. 13. 
kemiripan yang dimaksud adalah kemiripan yang dapat menimbulkan kesan adanya persamaan mengenai bentuk, cara penempatan, cara penulisan, atau kemiripan yang dapat menimbulkan kesan adanya persamaan mengenai bunyi ucapan yang terdapat dalam kedua merek tersebut. ${ }^{51}$ Dengan demikian diketahui bahwa hakim Pengadilan Niaga mempertimbangkan secara bertingkat suatu kemiripan dari kedua merek yang dipersengketakan. Namun demikian, dalam kedua putusan tersebut tidak ada yang mempertimbangkan bahwa adanya persamaan haruslah menimbulkan kebingungan (likelihood of confusion) di kalangan konsumen.

Perkara merek lain yang menarik adalah Extra Joss dan Enerjoss. PT Bintang Toedjoe sebagai pemilik merek Extra Joss mendalilkan bahwa kata 'joss' pada merek Extra Joss merupakan kata ciptaan (coined word) dengan asosiasi dan konotasi khusus yaitu energi dan/atau stamina. ${ }^{52}$ Selanjutnya juga diklaim bahwa jika kalangan masyarakat luas khususnya kalangan konsumen minuman kesehatan/minuman penambah tenaga akan secara otomatis mengasosiasikan kata 'joss' pada "kondisi stamina tubuh seseorang yang sehat atau prima dan/ atau kejantanan" ${ }^{53}$ Kata 'joss' sebenarnya bukan merupakan kata ciptaan baru yang sebelumnya tidak ada karena kata ini jamak digunakan khususnya di pulau Jawa yang artinya "luar biasa; hebat" jadi lebih tepatnya jika dikatakan bahwa PT Bintang Toedjoe hanya melekatkan kata joss yang sudah ada pada kata Extra sehingga membentuk merek Extra Joss. Sebagai satu merek, kata joss harus dilihat dalam kesatuan dengan kata 'extra' yaitu 'Extra Joss'. Jika dilihat demikian ditambah dengan bentuk, komposisi, unsur elemen, persamaan bunyi, ucapan dan penampilan, maka merek 'Enerjoss' berbeda dari merek 'Extra Joss'. Namun demikian, hakim hanya melihat adanya persamaan bunyi (suara) dan ucapan dari kata 'joss' untuk menentukan adanya persamaan pada pokoknya. Dalam kasus ini pun hakim tidak mempertimbangkan kemungkinan terjadinya kebingungan di kalangan konsumen.

Pemaparan di atas menjustifikasi argumen penulis bahwa kelemahan UU Merek berimplikasi pada tren negatif praktik ajudikasi kasus-kasus pelanggaran merek. Yang dimaksud dengan tren negatif tersebut adalah putusan dari ajudikasi kasus-kasus pelanggaran merek cenderung sumir sehingga hasil demikian sangat mudah untuk dikualifikasi sebagai tidak fair bagi pemilik merek yang mereknya dibatalkan semata-mata karena memiliki persamaan pada pokoknya dengan merek terdaftar milik pihak lain. Selain itu, situasi tidak fair tersebut terjadi karena UU Merek diterapkan sebatas berdasarkan literal meaning-nya sehingga hal itu tidak menyentuh hal-hal lebih esensial seperti aspek teleologis atau purposif dari Hukum Merek itu sendiri (dalam hal ini rationale untuk perlindungan merek). Dengan demikian penulis berpendapat bahwa kelemahan itu perlu dikoreksi.

\section{Amandemen Undang-Undang Merek dan} Ajudikasi yang Lebih Konstruktif dengan Hakikat Perlindungan Merek

Sebagai perbandingan, kecenderungan umum legislasi merek negara-negara lain dalam mendefinisikan konsep pelanggaran merek tidak hanya difokuskan pada unsur persamaan atau kemiripan dari merek yang disengketakan. Pola pengaturan demikian konsisten dengan semangat Art. 16.1 TRIPs Agreement. Satu contoh sangat spesifik adalah § 1114 UU Merek Amerika Serikat (the U.S. Trademark Act atau Lanham Act) yang mendefinisikan trademark infringement: ${ }^{54}$

(1) Any person who shall, without the consent of the registrant-

(a) use in commerce any reproduction, counterfeit, copy, or colourable imitation of a registered mark in connection with the sale, offering for sale, distribution, or advertising of

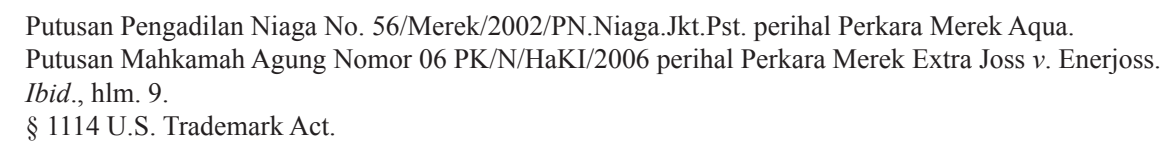


any goods or services on or in connection with which such use is likely to cause confusion, or to cause mistake, or to deceive; or

(b) reproduce, counterfeit, copy, or colourably imitate a registered mark and apply such reproduction, counterfeit, copy, or colourable imitation to labels, signs, prints, packages, wrappers, receptacles or advertisements intended to be used in commerce upon or in connection with the sale, offering for sale, distribution, or advertising of goods or services on or in connection with which such use is likely to cause confusion, or to cause mistake, or to deceive, shall be liable in a civil action by the registrant for the remedies hereinafter provided. Under subsection (b) hereof, the registrant shall not be entitled to recover profits or damages unless the acts have been committed with knowledge that such imitation is intended to be used to cause confusion, or to cause mistake, or to deceive.

Ketentuan dalam UU Merek Amerika Serikat secara spesifik menetapkan bahwa larangan-larangan tersebut disertai syarat apabila menyebabkan kebingungan, menyebabkan kesalahan atau untuk menyesatkan maka baru tindakan tersebut dapat dikualifikasikan sebagai pelanggaran merek (trademark infringement).

Menurut penulis, perubahan UU Merek Indonesia supaya konsisten dengan Art. 16.1 TRIPS Agreement adalah kebutuhan sangat mendesak. Seperti telah menjadi praktik lazim dalam ajudikasi, kelemahan dalam undang-undang memiliki potensi besar untuk menjadi insentif bagi praktik ajudikasi yang buruk (bad laws make bad decisions). Hal ini telah penulis jelaskan sebelumnya bahwa tidak memadainya UU Merek terbukti berbanding lurus dengan praktik ajudikasi atas kasus-kasus pelanggaran merek. Kondisi demikian tidak boleh dibiarkan terus berlanjut.

Idealnya, dalam UU Merek perlu ditambahkan secara khusus atau tersendiri ketentuan mengenai pelanggaran merek dan ketentuan mengenai halhal yang dapat dikecualikan dari pelanggaran merek. Atau sekurang-kurangnya mengubah ketentuan Pasal 6 UU Merek mengenai merek yang harus ditolak pendaftarannya apabila memiliki persamaan pada keseluruhannya/pokoknya dengan menambahkan klusula "apabila hal tersebut akan mengakibatkan timbulnya kebingungan (likelihood of confusion) di kalangan konsumen". Adapun usulan untuk ketentuan mengenai pelanggaran merek adalah sebagai berikut. Seseorang melanggar hak merek orang lain apabila menggunakan sebagai merek suatu tanda yang memiliki persamaan pada keseluruhannya atau sama pada pokoknya dengan merek milik orang lain untuk kelas barang atau jasa yang sama apabila hal tersebut akan mengakibatkan timbulnya kebingungan (likelihood of confusion) di kalangan konsumen.

Sedangkan usulan untuk ketentuan mengenai hal-hal yang dapat dikecualikan dari pelanggaran merek adalah sebagai berikut. Tanpa mengurangi ketentuan Pasal (mengenai pelanggaran merek), seseorang tidak dianggap melanggar merek jika merek digunakan dengan itikad baik, yang meliputi: merek adalah nama pribadi; nama tempat dimana usaha dijalankan, nama pendiri atau tempat usaha pendiri; merek digunakan untuk mengindikasikan jenis, kualitas, kuantitas, maksud penggunaan, nilai, asal geografis, atau karakteristik lain dari suatu barang/jasa; waktu produksi atau tahun dimulainya produksi barang dan/atau jasa.

Kedua usulan tersebut merupakan pengaturan dalam kondisi ideal yang lebih mencerminkan nuansa keadilan dalam perlindungan merek, khususnya untuk pembatalan melalui proses yudisial atau ajudikasi atas suatu merek yang dianggap melanggar merek orang lain. Namun demikian, tanpa perubahan seperti diusulkan diatas, hakim sesungguhnya tetap dapat melakukan tugasnya dengan lebih baik sepanjang bersedia mengubah cara berpikirnya. 
Dalam kaitan itu penulis berargumen bahwa hendaknya hakim lebih konstruktif dalam menjalankan ajudikasi dengan mengingat hakikat dari perlindungan merek. Sepanjang para hakim mampu berpikir dalam kerangka teori interpretasi purposif atau teleologis maka tanpa perubahan UU Merek sekalipun mereka tetap akan mampu memberikan kontribusi positif dalam rangka memberikan perlindungan merek. Justice Aharon Barak menjelaskan tentang teori interpretasi purposif sebagai berikut:

Purposive interpretation begins with the idea that interpretation is about pinpointing the legal meaning of a text along the spectrum of its semantic meanings. Semantic meaning sets the limits of interpretation. The interpreter may not give the text a meaning that its language cannot bear. A system of interpretation establishes criteria for determining the legal meaning of the text, within its semantic boundaries. In purposive interpretation, that criterion is the purpose of the text. It is the context according to which the text is interpreted. Purpose is the goals, interests, and values that the text seeks to actualize. It is a legal concept. The interpreter determines purpose according to the criteria that purposive interpretation establishes. That purpose has two components: subjective and objective. ${ }^{55}$

Pada pendapat di atas Barak meletakkan satu batasan yang sifatnya umum berkenaan dengan interpretasi yaitu penentuan makna dari teks harus masih tetap berada dalam batas-batas semantiknya. Pada interpretasi purposif maka purpose berfungsi sebagai konteks bagi teks yang diinterpretasi. Purpose adalah konsep yuridis yang meliputi tujuan, kepentingan atau nilai-nilai yang berusaha direalisasi atau diaktualisasi oleh teks, yang mengandung komponen subjektif maupun objektif.

Purpose di sini mengandung dua komponen, yaitu subjective component dan objective component. Selanjutnya Barak menjelaskan tentang subjective component dari purpose:
The subjective component is the goals, interests, and values - at various levels of abstraction - that the author of the text sought to actualize. It is the intent of the testator; the joint intent of the parties to a contract; the intent of the members of a legislative body; and the intent of the founders and amenders of a constitution. This subjective aspect reflects what the author or authors of the text actually intended its purpose to be, at the time they created it. Purposive interpretation translates that aspect into presumptions about the purpose of the legal text. The interpreter learns about subjective purpose from the text itself and from the circumstances surrounding its creation. The movement from text to the circumstances of its creation is free and free of technical restrictions. The interpreter need not determine that the text is unclear in order to justify consulting its context. ${ }^{56}$

Sementara tentang objective component dari purpose Barak memberikan penjelasannya sebagai berikut:

The objective component of purpose is the goals, interests, and values - at various levels of abstraction - that a text of the type being interpreted is designed to actualize. It is not related to the actual intent of the author. Rather, the author's hypothetical intent determines objective purpose. It reflects the social values prevalent at the time the text is interpreted, including values of morality and justice, social goals (like the public interest), proper modes of behaviour (like reasonableness and fairness), and human rights. These values appear before the interpreter in the form of presumptions of purpose. The interpreter gets information about this purpose from the text itself and from the legal system's values. Comparative law assists in this process. ${ }^{57}$

Dalam melakukan interpretasi purposif hakim hendaknya mengkombinasikan objective component dan subjective component dari purpose. Terkait dengan itu Barak memberikan catatan metodologis tentang proses tersebut, termasuk jika terjadi pertentangan antara objective component

\footnotetext{
Aharon Barak, 2005, Purposive Interpretation in Law, Princeton University Press, New Jersey, hlm. xiii.

Ibid.

Ibid., hlm. xiii-xiv.
} 
dan subjective component sebagai berikut:

The ultimate purpose of the text - which the interpreter uses to pinpoint its legal meaning along the spectrum of its semantic meanings - depends on the relationship between subjective and objective purpose. This relationship is easy to determine when the two purposes, and their presumptions, point in the same direction. When the two purposes - and the presumptions derived from them-conflict, purposive interpretation expresses its uniqueness by establishing the relationship between subjective and objective purpose according to the type of text in question. ${ }^{58}$

Jika para hakim sungguh-sungguh memiliki kapasitas atau kompetensi untuk memahami teori interpretasi purposif ini secara memadai maka penulis meyakini bahwa kelemahan dari UU Merek sejak awal sudah dapat tertanggulangi tanpa perlu dilakukan amandemen atau perubahan. Teori interpretasi purposif ini merupakan alat bantu bagi hakim dalam ajudikasi yang telah terkondisikan secara a priori bahwa UU Merek sebagai sumber hukum atau hukum material untuk ajudikasi tersebut mengandung kelemahan tekstual.

Kesadaran akan aspek purposif atau teleologis dari hakikat konsep perlindungan merek ini dapat menjadikan para hakim lebih substansial dan fair dalam memeriksa dan memutus kasus-kasus pelanggaran merek. Sekali lagi, yang dimaksud dengan aspek purposif atau teleologis dari hakikat konsep perlindungan merek ini adalah target gandanya dalam rangka "grants the trademark owner both a protection of the trademark's identity and a protection against confusion - exclusively, however, against unauthorized use by third parties". ${ }^{59}$ Dengan pengertian ini maka sejatinya, jika menggunakan teori interpretasi purposif, hakim sudah dapat membentuk suatu kaidah hukum yang solid dalam rangka perlindungan merek untuk menutup legal gap yang ada dalam UU Merek itu sendiri. Di sinilah kreativitas hakim untuk bermain dalam kerangka sistem hukum tersebut menjadi sangat mahal harganya.

\section{Kesimpulan}

Adanya merek yang sama atau mirip di dunia ini merupakan suatu keniscayaan dan upaya untuk menciptakan merek tunggal untuk setiap jenis barang jelas merupakan usaha yang hampir mustahil. Meskipun demikian, adanya kemiripan di antara dua merek tidak selalu berarti akan terjadi kebingungan (likelihood of confusion) pada konsumen. Dengan kalimat berbeda dapat dinyatakan bahwa adanya kemiripan pada merek tidak selalu membuat merek kehilangan daya pembeda. Dengan demikian syarat likelihood of confusion atau confusingly similar perlu untuk digunakan sebagai dasar pengujian untuk menentukan ada/tidaknya pelanggaran merek di Indonesia. Pemberlakuan syarat tersebut membuat Hukum Merek memenuhi esensinya sebagai hukum karena memiliki substansinya yang adil.

Indonesia sebagai Negara Pihak TRIPS Agreement memiliki kewajiban internasional untuk memenuhi ketentuan-ketentuan TRIPs Agreement dengan itikad baik. Namun sejak keikutsertaannya pada tahun 1994, Pemerintah Indonesia telah lalai mentransformasikan syarat likelihood of confusion atau confusingly similar untuk menilai ada/tidaknya pelanggaran merek ke dalam UU Merek. Kelalaian tersebut diperparah dengan pola pikir hakim yang sekedar menjadi corong undang-undang tanpa melakukan telaah dan perenungan mendalam ketika menguji kasus-kasus pelanggaran merek. Kondisi UU Merek dan case of law di Indonesia telah membuat hukum merek kehilangan esensinya sebagai hukum yaitu keadilan dengan adanya satu potensi besar bahwa seseorang dapat dibatalkan mereknya oleh pengadilan meskipun tidak terjadi kebingungan atau confusion pada konsumen karena yang bersangkutan tetap dapat membedakan produk barang atau jasa yang dia kehendaki.

$58 \quad$ Ibid., hlm. xiv.

59 Jan Hendrik Schmidt-Pfitzner, Loc.cit. 


\section{DAFTAR PUSTAKA}

\section{A. Buku}

Bainbridge, David I., 1999, Intellectual Property, Pitman Publishing, London.

Barak, Aharon, 2005, Purposive Interpretation in Law, Princeton University Press, New Jersey.

Bently, Lionel dan Brad Sherman, 2001, Intellectual Property Law, Oxford University Press, Oxford.

Peter-Tobias Stoll, Jan Busche dan Katrin Arend, 2009, WTO: Trade Related Aspects of Intellectual Property Rights, Martinus Nijhoff Publishers, Leiden-Boston.

\section{B. Artikel Jurnal}

Beebe, Barton, "An Empirical Study of the MultifactorTest for Trademark Infringement", California Law Review, Vol. 94, 2006.

Lemley, Mark A. dan Mark McKenna, "Irrelevant Confusion", Stanford Law Review, Vol. 62, 2009.

McKenna, Mark, "Testing Modern Trademark Law's Theory of Harm", Iowa Law Review, Vol. 95, 2009.

\section{Peraturan Perundang-undangan}

Undang-Undang Nomor 15 Tahun 2001 tentang Merek (Lembaran Negara Republik Indonesia Tahun 2001 Nomor 110, Tambahan Lembaran Negara Republik Indonesia Nomor 4131).

Undang-Undang Nomor 7 Tahun 1994 tentang Pengesahan Agreement Establishing The World Trade Organization (Persetujuan Pembentukan Organisasi Perdagangan Dunia) (Lembaran Negara Republik Indonesia Tahun 1994 Nomor 57).

\section{Putusan Pengadilan}

Putusan Mahkamah Agung Nomor 01/PK/N/HaKI 2003 perihal Perkara Merek 100 dan Lukisan. Putusan Mahkamah Agung Nomor 011 K/N/ HaKI/2004 perihal Perkara Merek AQUAAQUACUI.
Putusan Mahkamah Agung Nomor 014 K/N/ HaKI/2003 perihal Perkara merek AQUA AQUALIVA.

Putusan Mahkamah Agung Nomor 017 K/N/ HaKI/2003 perihal Perkara merek AQUA INDOQUALITY.

Putusan Mahkamah Agung Nomor 019 K/N/ HaKI/2005 perihal Perkara Merek NEW FUJITA - FUJITA.

Putusan Mahkamah Agung Nomor 020 K/N/ HaKI/2007 perihal Perkara Merek GS YUASA - GS GOLDSTAR.

Putusan Mahkamah Agung Nomor $025 \mathrm{~K} / \mathrm{N} /$ HaKI/2006 perihal Perkara Merek GAP GAPPA.

Putusan Mahkamah Agung Nomor 027 K/N/ HaKI/2003 Perihal Perkara Merek SUNSWET \& DEVICE - SUNDAY \& DEVICE.

Putusan Mahkamah Agung Nomor 027 K/N/ HaKI/2006 Perihal Perkara Merek VIM KHO - VIN KHO.

Putusan Mahkamah Agung Nomor 032 K/N/ HaKI/2003 perihal Perkara Merek PIONEER.

Putusan Mahkamah Agung Nomor 033 K/N/ HaKI/2003 perihal Perkara Merek AQUA AQUA Tiruan.

Putusan Mahkamah Agung Nomor $035 \mathrm{~K} / \mathrm{N} /$ HaKI/2003 perihal Perkara Merek AQUA AQUA Tiruan.

Putusan Mahkamah Agung Nomor 038K/N/ HaKI/2003 perihal Perkara Merek BONCAFE dan Logo.

Putusan Mahkamah Agung Nomor 06 PK/N/ HaKI/2004 perihal Perkara Merek Extra Joss v. Enerjoss.

Putusan Mahkamah Agung Nomor $08 \mathrm{~K} / \mathrm{N} /$ HaKI/2003 perihal Perkara Merek AKIRA.

Putusan Mahkamah Agung Nomor 138 PK/Pdt. Sus/2011 perihal Perkara Merek MALING.

Putusan Mahkamah Agung Nomor 165 PK/Pdt. Sus/2012 perihal Perkara Merek IKEA. 
Putusan Mahkamah Agung Nomor $177 \mathrm{~K} /$ Pdt. Putusan Mahkamah Agung Nomor 819 K/Pdt. Sus/2012 perihal Perkara Merek MAXIMA MAXISTYLE. Sus/2008 perihal Perkara Merek AMCO. Putusan Mahkamah Agung Nomor 975 K/Pdt. Sus/2005 perihal Perkara Merek GIORGIO.

Putusan Mahkamah Agung Nomor 202 K/Pdt. Sus/2010 perihal Perkara Merek IPSTAR BRADBAND SATELLITE - KIPSTAR.

Putusan Mahkamah Agung Nomor 292 K/Pdt. Sus/2009 perihal Perkara Merek POLO.

Putusan Mahkamah Agung Nomor 358 K/Pdt. Sus-HaKI/20103 perihal Perkara Merek KRAKATAU STEEL.

Putusan Mahkamah Agung Nomor 384 K/Pdt. Sus/2012 perihal Perkara Merek CHRISTIAN DIOR - CHARLES DIOR's.

Putusan Mahkamah Agung Nomor $400 \mathrm{~K} /$ Pdt. Sus/2011 perihal Perkara Merek INTERCONTINENTAL - INTERCONTINENTAL.

Putusan Mahkamah Agung Nomor $415 \mathrm{~K} / \mathrm{Pdt}$. Sus/2008 perihal Perkara Merek KNO3 (KENOTELU) - MEROKEKALINITRA dan KALINITRA.

Putusan Mahkamah Agung Nomor $445 \mathrm{~K} / \mathrm{Pdt}$. Sus/2012 perihal Perkara Merek TEFLON.

Putusan Mahkamah Agung Nomor 477 K/Pdt. Sus/2012 perihal Perkara Merek EVERLAST - EVER-LAST.

Putusan Mahkamah Agung Nomor 501 K/Pdt.SusHKI/2013 perihal Perkara Merek ALLADIN - ALADIN.

Putusan Mahkamah Agung Nomor 370 K/ Pdt.Sus/2008 perihal Perkara Merek SOPHOMORE INTERNATIONAL.

Putusan Pengadilan Niaga Nomor 56/Merek/2002/ PN.Niaga.Jkt.Pst. perihal Perkara Merek Aqua.

\section{E. Dokumen Lain}

Marrakesh Agreement Establishing the World Trade Organization, opened for signature 15 April 1994, 1867 UNTS 3 (entered into force 1 January 1995), annex $1 C$ (Agreement on Trade-Related Aspects of Intellectual Property Rights) 1867 UNTS 299, incorporating by reference the Paris Convention for the Protection of Industrial Property, opened for signature 14 July 1967, 828 UNTS 306 (entered into force 26 April 1970) ('Paris Convention') and the Berne Convention for the Protection of Literary and Artistic Works, opened for signature 14 July 1967, 828 UNTS 222 (entered into force 29 January 1970) ('Berne Convention').

The Restatement (First) of Torts (1938).

The TRIPs Agreement.

The U.S. Trademark Act. 